УДК 159.91; 159.92

\title{
РАЗВИТИЕ ТВОРЧЕСКОГО ПОТЕНЦИАЛА МЛАДШЕГО ШКОЛЬНИКА ПОСРЕДСТВОМ АРТ-ТЕРАПИИ
}

\author{
Ратенко Светлана Евгеньевна \\ к.пед.н., доцент \\ Кубанский государственный университет \\ Яковенко Елена Николаевна \\ к.филол.н., ст. преподаватель \\ ФГБОУ ВО «ГМУ \\ им. адм. Ф.Ф. Ушакова» \\ Яковенко Евгения Андреевна \\ студент
}

Кубанский государственный университет

Аннотация: Статья посвящена актуальной для современной психологии проблеме применения психотерапии в работе с детьми младшего школьного возраста, вопросам применения методик и техник арт-терапии для развития творческих способностей, приводятся примеры результативных приемов, направленных на развитие творческих способностей.

Ключевые слова: Арт-терапия, психотерапия, творческие способности, младший школьник, личность, потенциал.

\section{DEVELOPING THE CREATIVE POTENTIAL OF A YOUNGER STUDENT THROUGH ART THERAPY}

\author{
Ratenko Svetlana Evgenievna \\ Yakovenko Elena Nikolaevna \\ Yakovenko Evgeniya Andreevna
}

\begin{abstract}
The article is devoted to the problem of the use of psychotherapy in working with children of primary school age, relevant for modern psychology, the application of methods and techniques of art therapy for the development of creative
\end{abstract}




\section{СОВРЕМЕННЫЕ ТЕХНОЛОГИИ:

abilities, examples of effective techniques aimed at the development of creative abilities are given.

Key words: Art therapy, psychotherapy, creativity, junior high school student, personality, potential.

В современной школе будущего, то есть школе, работающей и развивающейся по новым стандартам и компетенциям, существует ряд проблем оставшихся из прошлого, таких, как проблема развития творческих способностей младших школьников. Проблемой, исследуемой на философском, культурологическом, педагогическом и психологическом уровнях, занимаются давно, и она является одной из важнейших общенаучных проблем на сегодняшний день.

Значительный вклад в изучение проблемы развития творческого потенциала детей на разных этапах их развития внесли отечественные и зарубежные исследователи, такие как Д.Б. Богоявленская, Н.В. Гнатко, В.Н. Дружинин, Де Боно, Дж. Гилфорд, А. Маслоу, С. Медник и многие другие $[6$, c.155].

Очевидно, что вопрос развития творческих способностей детей младшего школьного возраста волнует как педагогов, так и их родителей. Ребенок, развивая свои творческие способности, становится более уверенным в своих силах и может стать успешным в современном мире, который развивается и не стоит на месте. Творческие способности помогут ему достичь высот и принести максимальную пользу обществу в будущей профессиональной деятельности. Поэтому одной из задач педагога является помощь ребенку в закладке прочного фундамента для дальнейшей жизни, помощь воспитанникам найти свое место в жизни, развить потенциал в процессе учебной и творческой деятельности.

Если говорить о настоящем положении современной начальной школы в нашей стране, то стоит отметить, что основное место в ее деятельности занимает познавательная деятельность школьников, а творческая находится на заднем плане, хотя уже давно научно доказано, что именно младший школьный возраст является сензитивным периодом, то есть наиболее благоприятным отрезком времени для развития умений и навыков в жизни и творчестве ребенка. 


\section{СОВРЕМЕННЫЕ ТЕХНОЛОГИИ: ТЕНДЕНЦИИ И ПЕРСПЕКТИВЫ РАЗВИТИЯ}

Именно в младшем школьном возрасте закладывается психологическая основа для творческой деятельности. Развиваются воображение, творческое мышление, фантазия, проявляется любознательность, активность, инициатива, формируются умения наблюдать и анализировать явления, сравнивать и обобщать факты, делать выводы.

Одним из факторов успешного формирования у младших школьников творческих способностей является использование эффективных, педагогически целесообразных технологий обучения. Одной из таких технологий является «арт-педагогика» и ее смежный компонент« арт-терапия».

Психотерапивтическая работа с детьми младшего школьного возраста требует от педагога не только деликатности и осторожности, но также и использование особых методов работы. Далеко не все методы психотерапии, которые подходят для взрослого человека, одинаково хороши для детей младшего школьного возраста. У ребенка иной тип восприятия и мышления, дети более эмоциональны по своей природе и ими управляет не разум, а чувства.

Одним из наиболее безопасных методов является арт-терапия. Психотерапевтическая работа такого рода оказывает положительное влияние не только на эмоциональное состояние ребенка, но и способствует умственному и творческому развитию личности.

Применительно к детям арт-терапия имеет свои особенности и нюансы [3, с.64]. Для детей характерна гибкая и восприимчивая психика, и хотя они наиболее открыто выражают свои эмоции, чем взрослые, часто возникают сложности при установлении с ними контакта, так как они стеснительны и замкнуты в себе [5, с.32-33]. Поэтому при занятиях арт-терапией необходимо следовать некоторым обязательным принципам:

1) педагогу необходимо создать доброжелательную, уютную обстановку, в которой будет комфортно замкнутому и стеснительному ребенку;

2) при отборе материала и упражнений необходимо ознакомиться с возрастными особенностями и интересами детей;

3) важно помнить, что результат детского творчества в данный момент времени отражает его психоэмоциональное состояние. Если ребенок поделил лист бумаги хаотичными линиями, то это отражает хаос в душе ребенка, и задача педагога или психолога состоит в том, чтобы помочь ребенку 
разобраться в этом, не допустить негативного оценивания результата детского творчества [1, с.124];

4) поощрять и хвалить любое проявление творчества, стараясь поддерживать каждого участника сеанса арт-терапии, стараться находить в любом рисунке, поделке или танце что-то важное, значимое, индивидуальное;

5) организовывать занятия таким образом, чтобы у детей формировалось позитивное, доброжелательное и уважительное отношение к работам других детей;

6) не допускать злой критики и насмешек со стороны детей в адрес работ участников арт-терапии - дети часто бывают жестоки.

Арт-терапия рассматривается как совокупность методик, построенных на применении разных видов искусства, и имеет следующие формы:

1) изотерапия - воздействие изобразительным искусством, техникой письма, каллиграфией;

2) библиотерапия - воздействие чтением художественной литературы, сочинением стихов, сказок, рассказов, пьес;

3) имаготерапия - воздействие через образ, театрализацию;

4) музыкотерапия - воздействие через восприятие музыки, ее энергетику и вибрации;

5) вокалотерапия - воздействие пением;

6) кинезитерапия - воздействие движением;

7) танцтерапия - воздействие танцами [2, с.35].

Арт-технологии - это обучение интеллектуальной деятельности средствами художественного творчества. После занятий арт-терапией детям становится легче разбираться и воспринимать разные виды искусства( музыка, театр, живопись, литература). Главной задачей применения техник арт-терапии является помощь в освоении сложного учебного материала, то есть арт-терапия и искусство выступает здесь как средство познания, а не конечная цель. Решая поставленную познавательную задачу, учащийся младшего школьного возраста полностью или частично выбирает способы исполнения своей роли в соответствии с определёнными правилами игры. При этом у него остаётся достаточно степеней свободы, чтобы импровизировать, выдумывать, выбирать, догадываться, прогнозировать, то есть он в полной мере может реализовать свой творческий потенциал.

На данный момент чётко обозначились три варианта арт-уроков: 


\section{СОВРЕМЕННЫЕ ТЕХНОЛОГИИ:

1) акцентуация на одном виде искусства;

2) включение элементов искусства как средств деятельности учителя;

3) включение элементов искусства, как способа деятельности детей [2, c.37].

Выбор варианта и определяет структуру арт-урока. Примерами артуроков являются: театрализованный урок, урок имитационного моделирования, урок диалога культур, заочные путешествия, уроки предметного рисования, учебные игры, урок-пьеса, урок-концерт, урок-карнавал, урок танцевального шоу.

Театрализованный урок может по организации стать уроком-спектаклем, сказкой, карнавалом, экскурсией, концертом, и требует от учащихся серьезных усилий в работе с учебной литературой (выучить стихотворение, песню, роль), дополнительными источниками информации (поиск музыкального сопровождения, декораций), что способствует развитию интереса к обучению, творческой самостоятельности.

Любимыми для младших школьников становятся уроки с использованием изотерапии. Дети с удовольствием рисуют, лепят, конструируют, создают коллективные панно, картины, карты. Для арт-терапевтической работы необходимо иметь широкий выбор различных изобразительных материалов (карандаши, краски, мелки, фломастеры, пластилин) и сценариев (то есть задач, поставленных перед началом работы, например можно рисовать маршрут из дома до гимназии). Можно так же предложить детям придумать игру с данным видом искусства, например можно нарисовать« карту сокровищ», при этом на каждом этапе, выполняя действие, связанное с данным видом арт-терапии. Ученику должна быть предоставлена возможность самому выбирать тот или иной материал и средства для изобразительной работы [4, с.45]. В работе с арт-терапией могут использоваться не только классические материалы, но и различные предметы природы, такие как шишки, ветки, камни, листочки, цветы, кора деревьев, угольки (например, для рисования). Особенно нравится детям рисование нетрадиционными способами (пальчиками, ладонями, губкой, брызгами), это помогает ребенку лучше познать окружающий мир, потому что с помощью таких рисунков дети выражают свои эмоции, индивидуальность, творческий потенциал и креативный подход. Глина, тесто, песок и иные пластические материалы обладают значительными возможностями для выражения творчества. 


\section{СОВРЕМЕННЫЕ ТЕХНОЛОГИИ: ТЕНДЕНЦИИ И ПЕРСПЕКТИВЫ РАЗВИТИЯ}

Занятия такого рода позволяют развить в ребенке чувство прекрасного, сформировать вкус к искусству и творческой деятельности, воспитать трудолюбие, развить мелкую моторику рук, внимание, память [3, с.67].

Самым главным, на наш взгляд, является то, что каждый маленький художник создает свой неповторимый шедевр, получает удовольствие. Давая ребенку все пощупать и попробовать самому, мы расширяем границы его познания, творческие горизонты, так как испачканного краской ребенка легко отмыть водой и мылом, а подавленное желание творить может никогда уже не вернуться.

Положительный эффект дают занятия по сказкотерапии, который заключается в том, что ребенок мог сам придумать сюжет сказки и развить события, судьбы любимых персонажей. Кроме положительного творческого воздействия сказкотерапия положительно влияет на эмоциональное состояние младших школьников.

Кинезитерапия основывается на связи музыки и движения. Способность музыки захватывать своим ритмом, стимулировать и регулировать движения человеческого тела делает ее незаменимым компонентом разных видов кинезитерапии. Дети охотно осваивают данный вид арт-терапевтической практики, проявляют интерес и инициативу в постановке танца и различных номеров, тем самым проявляя свой творческий потенциал.

Самое главное, дать ребенку почувствовать ситуацию успеха $[7$, с.56]. Если ребенок будет получит поорение и одобрение со стороны сверстников и педагогов при выполнении той или иной техники арт-терапии, а именно при выражении своих эмоций, страхов, переживаний, при презентации своих уникальных рисунков, поделок, танца или сказки, то к нему придет успех в общении, а взаимодействие с миром станет более конструктивным и приятным, так как ребенок научится не только выражать свои чувства, но и понимать чувства окружающих его людей.

Проведение уроков с использованием арт-технологий - это мощный стимул в обучении и воспитании. Использование арт-технологий даёт возможность расширить и углубить уровень познавательной активности, пробудить в учащихся стремление к углубленному изучению учебного материала, развить творческие способности учащихся.

Арт-терапия является одной из технологий повышающей качество образовательного и воспитательного процессов [8, с.267]. Доказательством 
тому становится высокая активность младших школьников, участие в различных конкурсах, проектах, интеллектуальных играх и предметных олимпиадах. Для поддержания интереса необходимо устраивать для детей младшего школьного возраста различные творческие конкурсы и проводить мероприятия, приуроченные к каким-либо событиям и праздникам.

\section{Список литературы}

1. Аметова Л. А. Формирование арттерапевтической культуры младших школьников « Сам себе арттерапевт». М.: Московский государственный открытый педагогический университет, 2018. - 115 с.

2. Арт-терапевтические методы, используемые в работе с детьми и подростками // Журнал практической психологии и психоанализа. - 2017. - № 4. - С. 30-37.

3. Бетенски М. Что ты видишь? Новые методы арт-терапии. Серия «Ступени психотерапии». - СПб: Эксмо-пресс, 2016. - 258 с.

4. Богоявленская Д. Б. Психология творческих способностей. / Москва.: Издательский центр «Академия», 2018. - 320 с.

5. Венгер Н. Ю. Путь к развитию творчества // Вопросы психологии. 2019. - № 4. - C. 32-38.

6. Гликман И.3. Теория и методика воспитания/ И.З. Гликман // М.: Владос, 2002.-176с.

7. Выготский Л. Н. Вопросы детской психологии. - М., 1997. - 326 с.

8. Ковинько Л.В. Воспитание младших школьников. - М., 2010. - 288 с. 